\title{
Hyperphenylalaninaemia of various types among three-quarters of a million neonates tested in a screening programme
}

\author{
VALERIE WALKER, BARBARA E CLAYTON, R S ERSSER, \\ DOROTHY E M FRANCIS, PAMELA LILLY, J W T SEAKINS, ISABEL SMITH, \\ AND P D WHITEMAN \\ Department of Chemical Pathology, The Hospital for Sick Children, and Institute of Child Health, London
}

SUMMARY A total of 795382 infants born in north London was screened for phenylketonuria using the Guthrie test between October 1969 and December 1978. During this period it became recognised that phenylketonuria is not a single disease entity but one that encompasses a number of disorders of differing clinical and biochemical severity. The overall incidence of persistent hyperphenylalaninaemia was of the order of 7 per 100000 births (or 1 in 15000) and all the early treated patients made normal developmental progress. During the study there was an appreciable fall in the incidence of uncomplicated transient hyperphenylalaninaemia with or without tyrosinaemia. This reduction coincided with the change in infant feeding practice in the UK which led to lower intakes of protein and phenylalanine. It was concluded that any infant found to have a persistent blood phenylalanine concentration of $240 \mu \mathrm{mol} / 1(4 \mathrm{mg} / 100 \mathrm{ml})$ or greater should be followed closely.

In 1969 the Department of Health and Social Security ${ }^{1}$ published a recommendation that all infants born in the UK should be screened for phenylketonuria (PKU) by the detection of raised phenylalanine levels in blood using the microbiological inhibition assay of $\mathrm{Guthrie}^{2}$ or any other suitable method. This paper describes the experience of the neonatal screening laboratory at The Hospital for Sick Children, London. Between October 1969 and December 1978 the laboratory screened a total of 795382 infants, the great majority born in an area corresponding to that now under the auspices of the North East and North West Thames Regional Health Authorities. During the same period some 70000 babies born in the region were screened at other laboratories; these are excluded from this survey.

Since the start of the screening programme there have been major changes in infant feeding practice largely brought about by the document Present day practice in infant feeding which was published in 1974 by the Department of Health and Social Security. ${ }^{3}$ Infant milk formulae with a composition resembling full strength cows' milk and a high protein content have been replaced by preparations with a lower protein content more comparable to that of transitional human milk. The effects of this change on the results of screening are discussed.

\section{Procedures and laboratory methods}

Collection of specimens. On or after the sixth day of life and generally before the fourteenth day, capillary blood obtained by heel prick was collected on to absorbent cards (supplied by the DHSS, Code No HMR 101/6) which were then posted to the laboratory in protective plastic covers. Samples were rejected, and repeat collections obtained through the Community Health Service if the blood spots were too small, if the mother was breast feeding and taking antibiotics, or if the child was taking antibiotics, at the time of collection.

Screening for phenylalanine in the dried blood spot. The method ${ }^{4}$ was based on the principles given by Guthrie and Susi ${ }^{5}$ except that after December 1974 the Guthrie cards were not autoclaved before assay. Phenylalanine was semiquantitated by reference to standard blood spots containing 60-1200 $\mu \mathrm{mol} / \mathrm{l}$ $(1-20 \mathrm{mg} / 100 \mathrm{ml})$ phenylalanine assayed in parallel. 
A phenylalanine concentration of less than 240 $\mu \mathrm{mol} / 1(4 \mathrm{mg} / 100 \mathrm{ml})$ was accepted as a negative result provided some growth was visible around the disc on the Guthrie plate. Every positive test, no matter how small the increase in phenylalanine, was followed up until a negative screening test was obtained or a definitive diagnosis was reached. A repeat specimen was also requested if the sample showed a zone of growth inhibition around the blood spot indicating (probably) that the child was receiving antibiotics. Samples containing at least 600 $\mu \mathrm{mol} / \mathrm{l}(10 \mathrm{mg} / 100 \mathrm{ml})$, and samples in which inhibition was still present when a recall specimen was tested, were examined by thin layer chromatography (see below). If the initial screening test showed a phenylalanine concentration greater than $900 \mu \mathrm{mol} / \mathrm{l}$ $(15 \mathrm{mg} / 100 \mathrm{ml})$ the general practitioner was advised that further studies were essential, and the infant was brought to the hospital and usually admitted. The protein intake was reviewed and collections of a liquid sample of blood for quantitative measurement of phenylalanine and tyrosine, and of urine for chromatography for phenolic acids were made.

Semiquantitation of phenylalanine in dried blood spots using thin layer chromatography. This technique, which took 2 hours for an estimation, was used for the rapid confirmation of a raised phenylalanine concentration, and for exclusion of false-negative results due to antibiotics or other inhibitors when a zone of inhibition was visualised in the microbiological assay. Amino-acids were eluted from one $6 \mathrm{~mm}$ blood spot and chromatographed. ${ }^{6}$ Semiquantitation of phenylalanine concentration was made by eye using standard blood spots containing 420 and $900 \mu \mathrm{mol} / 1$ ( 7 and $15 \mathrm{mg} / 100 \mathrm{ml}$ ) which were eluted and chromatographed in parallel with the test sample. Increased concentrations of tyrosine and other amino-acids were detected by reference to a standard aqueous solution of amino-acids chromatographed in parallel.

Other biochemical methods. Quantitative determinations of phenylalanine and tyrosine in plasma by means of rapid ion exchange chromatography ${ }^{7}$ and examination of the urinary phenolic acid pattern by means of two-dimensional thin layer chromatography ${ }^{8}$ were always used before a low phenylalanine diet was introduced.

Selection of cases for treatment. Before 1973, patients with concentrations of phenylalanine above $1200 \mu \mathrm{mol} / 1$ and with low or normal tyrosine levels were started on a low phenylalanine diet as soon as confirmatory tests results were available. Patients with levels of phenylalanine of $1200 \mu \mathrm{mol} / 1$ or below were started on a modified milk providing 3-4 g protein $/ \mathrm{kg}$ a day, and followed by daily phenylalanine measurements. Those with phenylalanine levels of $900 \mu \mathrm{mol} / 1$ or greater on this regimen were also started on a low phenylalanine diet, and the others were followed up on the modified milk. Since 1973 all patients have been either breast fed or placed on a whey-based modified milk (for example, Gold Cap SMA) providing $2 \cdot 2-3 \mathrm{~g}$ protein $/ \mathrm{kg}$ a day before confirmary measurements of phenylalanine and tyrosine, and any patient with a phenylalanine concentration of $900 \mu \mathrm{mol} / \mathrm{l}$ or greater was treated with a low phenylalanine diet. Untreated cases were followed up to ensure that blood phenylalanine concentrations were maintained below $900 \mu \mathrm{mol} / 1$. The decision on whether to use a diet was not influenced by the presence or absence of an excess of phenolic acids in the urine.

Continuous assessment of the need to continue treatment was made by recording the natural protein intake required to maintain blood phenylalanine levels in the range 180 to $480 \mu \mathrm{mol} / \mathrm{l}$ ( 3 to 8 $\mathrm{mg} / 100 \mathrm{ml}$ ). An intake of $10 \mathrm{~g}$ natural protein (providing $500 \mathrm{mg}$ phenylalanine) or more was taken to indicate the possibility of a mild or 'variant' type of PKU. In addition, at some time during the first year, and at an early stage if the natural protein intake was fairly high, all patients received a trial when well of an extra $9 \mathrm{~g}$ protein $(450 \mathrm{mg}$ phenylalanine) a day ${ }^{9}$ for at least a week to ensure that blood phenylalanine levels would rise to $1200 \mu \mathrm{mol} / \mathrm{l}$. The extra protein was additional to that required to keep blood concentrations between 180 and 480 $\mu \mathrm{mol} / \mathrm{l}$. If the level in any patient did not rise to $1200 \mu \mathrm{mol} / 1$ within a week, the intake of natural protein was increased to $2 \mathrm{~g} / \mathrm{kg}$ a day. If the phenylalanine level in any patient remained persistently below $900 \mu \mathrm{mol} / \mathrm{l}$ on this regimen he was given a trial of a normal protein intake and then placed on an unrestricted diet. The aim of this approach was not so much to define 'classical' and the various types of 'atypical' PKU, but to find out the need for treatment of the hyperphenylalaninaemia and to see how strict the low phenylalanine diet had to be.

Patients with persistent increase in blood phenylalanine. Fifty-three infants, 31 of them boys, with persistently high blood phenylalanine levels $(>240$ $\mu \mathrm{mol} / \mathrm{l})$ were detected in the screening programme between 1969 and 1978. One infant, the child of a 1st-cousin marriage, had histidinaemia as well as phenylketonuria. Fifty-one infants, 29 of them boys, were judged to require treatment by means of a low phenylalanine diet (see left column). 
Seven of the treated infants consistently tolerated $10 \mathrm{~g}$ or more of natural protein in the diet and had blood phenylalanine levels between 900 and 1200 $\mu \mathrm{mol} / 1$ after one week of an extra $9 \mathrm{~g}$ of natural protein in the diet. They appear to have a 'variant' type of phenylketonuria. Another 5 infants also tended to have a higher than average tolerance to dietary phenylalanine but only occasionally had a natural protein intake as high as $10 \mathrm{~g} /$ day. Of these, 3 also had phenylalanine levels between 900 and $1200 \mu \mathrm{mol} / \mathrm{l}$ after one week of extra protein, and they too probably suffer from a 'variant' type of disorder, but the other 2 infants who were being treated at other hospitals were not given extra protein. Thirty-nine infants tolerated between 3 and $6 \mathrm{~g}$ of natural protein a day and had blood phenylalanine levels above $1200 \mu \mathrm{mol} / \mathrm{l}$ after one week of extra protein, many of them after 48 hours. They appear to have a 'classical' type of PKU but it is noteworthy that 2 of them had negative tests for phenolic acids in the urine during the neonatal period. These tests became positive after protein loading. Two infants had persistently mild increases in blood phenylalanine levels (never greater than $500 \mu \mathrm{mol} / 1(8 \mathrm{mg} / 100 \mathrm{ml})$ ) with normal tyrosine and other amino-acid levels. They remained on a free diet and both infants thrived and have made normal developmental progress.

The aim of treatment is to continue the strict low phenylalanine diet up to age 8 years and maintain blood concentrations between 180 and $480 \mu \mathrm{mol} / \mathrm{l}$ in all 'classical' and 'variant' patients whose blood phenylalanine levels rise to $900 \mu \mathrm{mol} / \mathrm{l}$ or greater on a normal diet. At age 8 years the amount of natural protein in the diet is increased to allow blood phenylalanine levels to increase to between 900 and 1200 $\mu \mathrm{mol} / \mathrm{l}$ while a supplement of phenylalanine-free protein substitute is continued. All patients with 'classical' phenylketonuria and most 'variant' patients remain on a low phenylalanine diet at follow-up. Three variant patients stopped treatment before age 8 years. In one, the combination of 'variant' disorder with a very disturbed social background as well as the knowledge that an 18-monthold brother with the same biochemical disorder appeared to be making normal developmental progress led to a decision to stop treatment at age 6 months. When 4 years old this patient and his untreated brother had IQs in the borderline ESN range and attended schools for disruptive children. Two other 'variant' patients, whose blood phenylalanine levels remained below $900 \mu \mathrm{mol} / 1$ on $2 \mathrm{~g}$ protein $/ \mathrm{kg}$ a day when rechallenged with protein at age 2 years, were also put on an unrestricted diet. At 4 years the patients' IQs were 87 and 128 and were appropriate for their family backgrounds.
All the children remaining on the diet have made normal developmental progress. The mean IQ at 4 years (for those already 4 years) is $103.9(\mathrm{SD} \pm 12 \cdot 6$ ), 'classical' patients having a mean of 103.8 and 'variant' patients a mean of 104.3.

Patient with phenylketonuria missed in the screening programme. One patient whose blood specimen was screened at 6 days and reported as negative presented at age 2 years with moderately delayed development, particularly of speech. He was found to have an increased blood phenylalanine level $(1200 \mu \mathrm{mol} / \mathrm{l})$ and retesting of the original Guthrie screening card showed a concentration of $>1200 \mu \mathrm{mol} / \mathrm{l}$. The reason for the negative result of the original test could not be found. When the child was treated with a low phenylalanine diet he had a fairly high tolerance to dietary phenylalanine (10-14 g natural protein/day) and at age 4 years he has an IQ of 85 . $\mathrm{He}$ too appears to have a 'variant' form of phenylketonuria.

Patients with transient hyperphenylalaninaemia. Excluding the peak incidence of positive first tests in 1969-70 (488 and 333 per 100000 screened; Table 1) at the start of the programme, the overall incidence of such tests (that is, positive first tests followed by normal levels on recall samples) was 84 per 100000 . Apart from the infants with persistent hyperphenylalaninaemia, 60 infants, 32 of them boys, had raised blood phenylalanine concentrations with or without raised tyrosine levels or generalised aminoacidaemia on the second test. An additional patient left for the USA at age 6 weeks and could not be followed up, but he had a phenylalanine level at 17 days of $240-360 \mu \mathrm{mol} / 1(4-6 \mathrm{mg} / 100 \mathrm{ml})$ with a moderately raised methionine concentration (240$402 \mu \mathrm{mol} / \mathrm{l}(4-6 \mathrm{mg} / 100 \mathrm{ml}))$. Phenylalanine concentrations at 26 and 33 days were 600 and 480 $\mu \mathrm{mol} / \mathrm{l}$ respectively and the methionine levels remained raised.

Uncomplicated transient tyrosinaemia with hyperphenylalaninaemia. This was present in 33 infants, 21 of them boys. The sex difference was not statistically significant $(P>0 \cdot 10)$. Only one infant was affected by transient tyrosinaemia after 1974 . The change in incidence $(6 \cdot 6 / 100000$ to $0 \cdot 3 / 100000)$ is highly significant (Table 2). Although clinical information was not always available, 7 infants are known to have been twins, 6 of the others were preterm, and 2 more were born at 37 weeks' gestation. Three of the remaining infants were recorded as receiving high dietary protein intakes. The highest phenylalanine concentration observed in each infant ranged from 240 to $1200 \mu \mathrm{mol} / \mathrm{l}$. Tyrosine was semiquantitated 
762 Walker, Clayton, Ersser, Francis, Lilly, Seakins, Smith, and Whiteman

Table 1 Infants with positive tests on neonatal screening for raised phenylalanine

\begin{tabular}{|c|c|c|c|c|c|c|c|c|c|}
\hline \multirow[t]{2}{*}{ Year } & \multirow{2}{*}{$\begin{array}{l}\text { Total } \\
\text { number } \\
\text { screened }\end{array}$} & \multicolumn{2}{|c|}{ Positive first tests } & \multicolumn{2}{|c|}{$\begin{array}{l}\text { Persistent } \\
\text { hyperphenylalaninaemia }\end{array}$} & \multicolumn{4}{|c|}{$\begin{array}{l}\text { Positive second tests excluding } \\
\text { persistent hyperphenylalaninaemia }\end{array}$} \\
\hline & & No & $\begin{array}{l}\text { Incidence per } \\
100000\end{array}$ & Total & Boys & Total & Boys & $\begin{array}{l}\text { Gender not } \\
\text { known }\end{array}$ & $\begin{array}{l}\text { Total per } \\
100000\end{array}$ \\
\hline $\begin{array}{l}1969 * \\
1970 \\
1971 \\
1972 \\
1973 \\
1974 \\
1975 \\
1976 \\
1977 \\
1978 \\
\text { Total } \\
\end{array}$ & $\begin{array}{r}9215 \\
102376 \\
103540 \\
96286 \\
91017 \\
82523 \\
77439 \\
76794 \\
76031 \\
80161 \\
795382\end{array}$ & $\begin{array}{r}45 \\
374 \\
124 \\
104 \\
51 \\
25 \\
151 \\
101 \\
33 \\
67 \\
1075 \\
\end{array}$ & $\begin{array}{r}488 \\
333 \\
107 \\
90 \\
41 \\
12 \\
191 \\
122 \\
38 \\
74\end{array}$ & $\begin{array}{l}0 \\
7 \\
6 \\
9 \\
9 \\
6 \\
3(+1) \dagger \\
6 \\
3 \\
3(+1) \\
53(+1) \dagger\end{array}$ & $\begin{array}{c}0 \\
6 \\
3 \\
5 \\
5 \\
2 \\
1(+1) \dagger \\
2 \\
3 \\
3(+1) \\
31(+1) \dagger\end{array}$ & $\begin{array}{r}0 \\
26 \\
6 \\
8 \\
5 \\
9 \\
0 \\
1 \\
1 \\
4 \\
60\end{array}$ & $\begin{array}{r}0 \\
16 \\
1 \\
7 \\
3 \\
3 \\
0 \\
0 \\
1 \\
1 \\
32\end{array}$ & $\begin{array}{l}0 \\
2 \\
1 \\
0 \\
0 \\
0 \\
0 \\
0 \\
0 \\
0 \\
3\end{array}$ & $\begin{array}{r}0 \\
25.4 \\
5.8 \\
8.3 \\
5.5 \\
12.0 \\
0 \\
1.4 \\
1.4 \\
5.0\end{array}$ \\
\hline
\end{tabular}

* Screening started 1 October 1969. † The case of PKU missed on screening.

Table 2 Incidences of uncomplicated transient hyperphenylalaninaemia: 1969-74 and 1975-78

\begin{tabular}{|c|c|c|c|c|c|c|}
\hline \multirow{3}{*}{ Period } & \multirow{3}{*}{ Total number screened } & \multicolumn{5}{|c|}{ Uncomplicated transient hyperphenylalaninaemia } \\
\hline & & \multicolumn{2}{|c|}{$\begin{array}{l}\text { Raised phenylalanine } \\
\text { only }\end{array}$} & \multicolumn{2}{|c|}{$\begin{array}{l}\text { With transient } \\
\text { tyrosinaemia }\end{array}$} & \multirow[t]{2}{*}{$\begin{array}{l}\text { With transient generalised, } \\
\text { aminoacidaemia }\end{array}$} \\
\hline & & No & $\begin{array}{l}\text { Incidence per } \\
100000\end{array}$ & No & $\begin{array}{l}\text { Incidence per } \\
100000\end{array}$ & \\
\hline 1969-74 & 484957 & 20 & $4 \cdot 1$ & 32 & $6 \cdot 6$ & $2+1 \dagger$ \\
\hline $1975-78$ & 310425 & $2 *$ & 0.6 & $1 *$ & $0 \cdot 3$ & $\mathbf{0}$ \\
\hline Total & 795382 & 22 & $2 \cdot 2$ & 33 & $4 \cdot 1$ & 2 \\
\hline
\end{tabular}

* Incidences in the period 1975-78 significantly lower than in the period 1969-74 (transient hyperphenylalaninaemia without other amino-acid increase, $\mathbf{P}<0.01$, transient tyrosinaemia, $\mathbf{P}<0.001$ ).

$\dagger$ Raised methionine only. Lost to follow-up.

in 25 infants, the maximum concentration ranging from 276 to $2475 \mu \mathrm{mol} / \mathrm{l}(5$ to $45 \mathrm{mg} / 100 \mathrm{ml})$, being at least $1100 \mu \mathrm{mol} / 1(20 \mathrm{mg} / 100 \mathrm{ml})$ in 20 infants. The phenylalanine had fallen to normal by 14-67 days of life, although in many infants the tyrosine concentration remained raised for longer. Three infants had a slightly increased methionine concentration and one a transiently increased histidine level.

Transient hyperphenylalaninaemia without tyrosinaemia. This was present in 22 infants ( 9 boys; 12 girls, sex unknown in 1). Only 2 infants have been detected since 1974, and again the change in incidence $(4 \cdot 1 / 100000$ to $0 \cdot 6 / 100000)$ is statistically significant (Table 2). The maximum phenylalanine concentration was 240 to $1080 \mu \mathrm{mol} / \mathrm{l}$ ( 4 to 18 $\mathrm{mg} / 100 \mathrm{ml}$ ) in 20 infants, and in 17 of these a normal concentration was recorded by 19-76 (mean 36) days of life. In 3 others, follow-up was incomplete, but the concentration had fallen to nearly normal when last tested. Two infants had phenylalanine levels above $1200 \mu \mathrm{mol} / \mathrm{l}$. In one the concentration increased from $360 \mu \mathrm{mol} / 1(6 \mathrm{mg} / 100 \mathrm{ml})$ at 7 days to $1800 \mu \mathrm{mol} / 1(30 \mathrm{mg} / 100 \mathrm{ml})$ at 21 days, but had fallen to normal by 31 days on a normal protein intake. The baby was born at term and thrived, and no explanation could be found for the single high value. In the other, the phenylalanine increased from $720 \mu \mathrm{mol} / 1(12 \mathrm{mg} / 100 \mathrm{ml})$ at 8 days of life to 1200 $\mu \mathrm{mol} / 1$ and $2400 \mu \mathrm{mol} / 1(40 \mathrm{mg} / 100 \mathrm{ml})$ at 14 and 17 days respectively. He was receiving a high protein milk at this time. A provisional diagnosis of PKU was supported by finding a low-normal blood tyrosine concentration and increased urinary excretion of O-hydroxy-phenylacetic acid. However, the blood phenylalanine levels fell precipitously to normal on a protein intake of $3 \mathrm{~g} / \mathrm{kg}$ a day. The infant thrived and was discharged on a free intake of Gold Cap SMA (Wyeth Ltd).

Hyperphenylalaninaemia associated with generalised aminoacidaemia. This was detected in 6 infants, one on the initial Guthrie test and 5 on recall tests. Two (screened in 1970 and 1973) had generalised aminoacidaemia which resolved uneventfully within a month; no cause was found. A third child (in 1977) had a blood phenylalanine concentration of 720 
$\mu \mathrm{mol} / \mathrm{l}$ at 6 days together with a generalised aminoacidaemia (including raised tyrosine). Although apparently well apart from mild jaundice at the time of this test, he was admitted to another hospital aged 9 days with fulminating galactosaemia. Three further children (screened in 1978) had generalised aminoacidaemia, including increased phenylalanine and tyrosine concentrations: one died at 12 days, and had evidence of severe liver damage at necropsy, the second had liver damage secondary to abdominal sepsis, and the third probably had mild neonatal hepatitis which resolved.

Changes in pattern of infant feeding. In 1974, the Department of Health and Social Security ${ }^{3}$ recommended that modified milks, rather than those with the composition of full strength cows' milk, should be given to bottle-fed infants until at least 6 months of age. Analysis of the types of feeds that infants who were later treated for PKU had received before hospital admission, probably gives a representative picture of the infant feeding practices in the north London region, since they were not a selected group so far as feeding was concerned before the positive Guthrie test. Information was available for $\mathbf{4 0}$ infants (Table 3). ${ }^{10-12}$ The average phenylalanine concentration of feeds received by infants born after 1974 was significantly lower $(P<0.001)$ than that of the feeds received by infants born in 1974 or

Table 3 Estimated protein and phenylalanine concentrations in feeds of 40 neonates with PKU at the time of the first Guthrie test

\begin{tabular}{llllll}
\hline Period & $\begin{array}{l}\text { No of } \\
\text { infants }\end{array}$ & \multicolumn{2}{l}{ *Protein $(\mathrm{g} / \mathrm{l})$} & \multicolumn{2}{l}{$*$ Phenylalanine $(\mathrm{mg} / \mathrm{l})$} \\
\cline { 3 - 6 } & & Mean & $S D$ & Mean & $S D$ \\
\hline $1969-74$ & 26 & 23.5 & 5.8 & 1112 & 331 \\
$1975-78$ & 14 & 17.5 & 2.4 & 680 & 100 \\
\hline
\end{tabular}

* Sources used in estimating these concentrations: (1) human milk: mean concentrations for transitional milk-protein $20 \mathrm{~g} / \mathbf{1}^{10}$, phenylalanine $630 \mathrm{mg} / 1.11$ (2) Protein contents of other milks: Francis. 12 (3) Phenylalanine concentration of SMA Gold Cap and SMA (Wyeth): manufacturers' literature. (4) Phenylalanine concentration of other milks estimated as $50 \mathrm{mg}$ phenylalanine per $\mathrm{g}$ of protein. before. The more pronounced fall observed in phenylalanine compared with protein reflects the use of whey-containing milks. Eleven infants were breast fed initially: 5 of those diagnosed in the period 1969 to 1974 , and 6 in the period 1975 to 1978.

Phenylalanine concentrations exceeding 1200 $\mu \mathrm{mol} / \mathrm{l}$ were found in 12 out of 15 infants receiving high protein feeds at the time of the screening test compared with 15 out of 25 on breast or modified milks. No child with phenylketonuria was found later to have a low tolerance to phenylalanine (that is of 'classical' type of PKU) and a blood phenylalanine level of less than $720 \mu \mathrm{mol} / \mathrm{l}$ on Guthrie testing, whether fed on breast, modified or high protein milk initially, and only one 'variant' patient, who was receiving a modified milk, had a level below $720 \mu \mathrm{mol} / \mathrm{l}$ at the first test (Table 4).

\section{Discussion}

It is now known that PKU is not a single disease entity but one that encompasses a number of disorders of differing clinical and biochemical severity. Most patients with persistent hyperphenylalaninaemia have one of several defects of phenylalanine hydroxylase activity, ${ }^{13}$ although a few rare patients have abnormalities of biopterin metabolism. ${ }^{14}$ None of the patients detected in the screening programme described here has had symptoms that suggest disorders of biopterin metabolism. However, the possibility that mild symptomless defects of biopterin metabolism could be present in some 'variant' cases has not been excluded.

The overall incidence of persistent hyperphenylalaninaemia in the north London region appears to be of the order of 7 per 100000 births (or 1 in 15000 ) including the 'missed' case and is similar to that found in Massachusetts ${ }^{15}$ but lower than in many other parts of the UK during a 5-year period. ${ }^{16}$ For example, a comparable incidence for Northern Ireland for 1974-78 was 28 per 100000 births and for North-west England (including Liverpool and Manchester) was 12 per 100000 . The incidence of

Table 4 Phenylalanine concentrations at initial screening test in infants with PKU and relationship to type of feeding

\begin{tabular}{|c|c|c|c|c|c|c|}
\hline \multirow{2}{*}{$\begin{array}{l}\text { Infants with } \\
\text { phenylketonuria } \\
(n=40)\end{array}$} & \multicolumn{6}{|c|}{ Number of infants with blood phenylalanine concentration ( $\mu \mathrm{mol} / \mathrm{l})$ in each category } \\
\hline & $\begin{array}{l}240-480 \\
(4-8 \mathrm{mg} / 100 \mathrm{ml})\end{array}$ & $\begin{array}{l}>480-600 \\
(>8-10 \mathrm{mg} / 100 \mathrm{ml})\end{array}$ & $\begin{array}{l}>600-720 \\
(>10-12 \mathrm{mg} / 100 \mathrm{ml})\end{array}$ & $\begin{array}{l}>720-900 \\
(>12-15 \mathrm{mg} / 100 \mathrm{ml})\end{array}$ & $\begin{array}{l}>900-1200 \\
(>15-20 \mathrm{mg} / 100 \mathrm{ml})\end{array}$ & $\begin{array}{l}>1200 \\
(>20 \mathrm{mg} / 100 \mathrm{ml})\end{array}$ \\
\hline $\begin{array}{c}\text { Low protein } \\
\text { tolerance }\end{array}$ & 0 & 0 & 0 & $6(4)$ & $4(4)$ & $25(14)$ \\
\hline High protein & 0 & $1(1)^{*}$ & 0 & 0 & $2(1)$ & $2(1)$ \\
\hline
\end{tabular}

* Figures for infants who were breast fed or received a modified milk are shown in brackets. 
'classical' PKU for north London is of the order of 5 per 100000 births. As in previous surveys, early treated patients made normal developmental progress.

Perhaps the most interesting finding to emerge from this study is the significant fall in the incidence of uncomplicated transient hyperphenylalaninaemia with or without tyrosinaemia. This fall coincided with the change in infant feeding practice in the UK, which led to lower intakes of protein and phenylalanine intake in infants born after 1974 and is likely to be due to the change in feeding. A similar explanation has been proposed to account for the decreased incidence of transient hypermethioninaemia and homocystinuria detected in recent years in the same north London screening area. ${ }^{17}$ At the present time, the finding of moderately raised phenylalanine levels which persist at repeat testing merit speedy investigation, especially when associated with raised tyrosine levels or generalised aminoacidaemia, and may constitute an emergency. Of the 5 infants detected with raised tyrosine levels since 1974, only 1 had uncomplicated transient tyrosinaemia of the newborn; the other 4 had liver damage.

There appears to have been some tendency for the change in feeding practice to lower the phenylalanine concentrations found at screening of patients who later turn out to have some form of PKU needing treatment. However, of the 39 children with 'classical' PKU detected by screening in north London, none had a phenylalanine concentration below $900 \mu \mathrm{mol} / 1$ at the first test, irrespective of the type of milk being fed. Our experience so far thus accords with the prediction of Saudubray and Charpentier ${ }^{18}$ that the use of low protein milks should not decrease the frequency of detection of 'classical' PKU. However, 'variant' cases may have phenylalanine levels only just above the normal range while receiving modified milks. ${ }^{19}$ The introduction of weaning solids and change to cows' milk can greatly increase the protein intake of young children. In those with persistently high blood phenylalanine concentrations such an increase in dietary protein/phenylalanine may cause further increases. Such infants should be seen by a paediatric team experienced in the care of patients with PKU and concentrations of blood phenylalanine should be monitored. We would advocate that any infant found to have a phenylalanine concentration of $240 \mu \mathrm{mol} / 1$ or above which is persistent, should be followed closely.

We thank Professor O H Wolff for permission to study his patients.

\footnotetext{
References

1 Department of Health and Social Security. Screening for early detection of phenylketonuria. $\mathrm{HM}(69) 72$. London: HMSO, 1969.
}

2 Guthrie R. Letter: Blood screening for phenylketonuria. JAMA $1961 ; 178$ : 863 .

3 Department of Health and Social Security. Present day practice in infant feeding. Reports on Health and Social Subjects No 9. London: HMSO, 1974.

${ }^{4}$ Lemag Working Party. Estimation of blood phenylalanine from a dried blood spot using the Guthrie test. $J$ Clin Pathol 1971; 24: 576-8.

${ }^{5}$ Guthrie R, Susi A. A simple phenylalanine method for detecting phenylketonuria in large populations of newborn infants. Pediatrics $1963 ; 32$ : 338-43.

${ }^{6}$ Ersser R S, Smith I. Amino acids and related compounds. In: Smith I, Seakins J W T, eds. Chromatographic and electrophoretic techniques, fourth edition. Vol. 1. London: Heinemann Medical, 1976: 75-109.

7 Ersser R S. Rapid quantitative determination of plasma phenylalanine and tyrosine by automated ion-exchange chromatography using an internal standard. Med Lab Sci 1976; 33: 57-61.

${ }^{8}$ Ersser R S, Oakley S E, Seakins J W T. Urinary phenolic acids by thin-layer chromatography. Clin Chim Acta $1970 ; 30$ : 243-9.

9 Smith I, Francis D E M. Disorders of amino acid metabolism. In: McLaren D S, Burman D, eds. Textbook of paediatric nutrition. Edinburgh: Churchill Livingstone, 1976: 263-93.

10 Paul A A, Southgate D A T, eds. McCance and Widdowson's The composition of foods, fourth edition. London: HMSO, 1978: 78; 280; 303.

11 Macy I G, Kelly H J. Human milk and cows' milk in infant nutrition. In: Kon S K, Cowie A T, eds. Milk: the mammary gland and its secretion. Vol. 2. New York: Academic Press, 1961: 265-304.

12 Francis D E M. Diets for sick children, third edition. Oxford: Blackwell, 1974: 8-9.

13 Kaufman S. The enzymes of the hepatic phenylalanine hydroxylating system. J Inher Metabol Dis 1978; 1 : 63-5.

14 Danks D M, Bartholomé K, Clayton B E, et al. Malignant hyperphenylalaninaemia-current status (June 1977). J Inher Metabol Dis 1978; 1 : 49-53.

15 Massachusetts Department of Public Health. Newborn screening for metabolic disorders. N Engl J Med 1973; 288: 1299-300.

16 Medical Research Council/Department of Health and Social Security. Phenylketonuria register newsletter. London: Phenylketonuria Register Office, Institute of Child Health, 1978: 1-3.

17 Whiteman P D, Clayton B E, Ersser R S, Lilly P, Seakins J W T. Changing incidence of neonatal hypermethioninaemia : implications for the detection of homocystinuria. Arch Dis Child 1979; 54: 593-8.

18 Saudubray J M, Charpentier C. Les pieges due test de Guthrie. Arch Fr Pediatr 1976; 33: 915-20.

19 Burman D, Holton J B, Morris A F. Factors determining blood phenylalanine in the neonatal period. Clin Chim Acta 1975; 62: 325-31.

Correspondence to Professor B E Clayton, South Laboratory and Pathology Block, Level D, Southampton General Hospital, Tremona Road, Southampton SO9 4XY.

Received 26 June 1980 